Jurnal Sains \& Teknologi Modifikasi Cuaca, Vol.19 No.2, 2018: 61 - 68

\title{
APLIKASI SATELIT DALAM MENGESTIMASI EVAPORASI DI DAERAH WADUK (STUDI KASUS: WADUK SAGULING-JAWA BARAT)
}

\author{
Application of Satellite on the Evaporation Estimation of a Reservoir Area \\ (Case Study: Saguling Reservoir-West Java)
}

\author{
Rusmawan Suwarman1) ${ }^{*}$, Dinda Mahardita2), ( Dewa Gede A. Junnaedhi') \\ 1) Kelompok Keahlian Sains Atmosfer, Fakultas Ilmu dan Teknologi Kebumian, \\ Institut Teknologi Bandung, Jl. Ganesha No.10, Bandung, Jawa Barat \\ 2) Program Studi Meteorologi, Fakultas IImu dan Teknologi Kebumian, \\ Institut Teknologi Bandung, Jl. Ganesha No.10, Bandung, Jawa Barat \\ *E-mail: rusmawan@meteo.itb.ac.id
}

\begin{abstract}
Intisari
Estimasi evaporasi di daerah waduk menggunakan metode empiris dengan input data satelit dilakukan untuk mengatasi masalah ketersediaan data meteorologi dari observasi permukaan. Data satelit berupa Land Surface Temperature dari satelit Himawari dan profil atmosfer dari satelit MODIS digunakan untuk memperoleh informasi parameter temperatur, kelembapan relatif dan radiasi matahari untuk mengestimasi besaran evaporasi di daerah waduk. Metode empiris yang digunakan antara lain adalah Blaney-Criddle, Kharuffa, Hargreaves, Schendel dan Schendel yang dimodifikasi (Modified Schendel). Hasil estimasi evaporasi dibandingkan terhadap evaporasi acuan yang dihitung menggunakan metode kombinasi (Penman) dengan input parameter meteorologi hasil observasi. Observasi dilakukan menggunakan Automatic Weather Station di dua titik pengamatan di Waduk Saguling. Hasil penelitian menunjukkan estimasi evaporasi waduk dengan input data satelit dapat dilakukan dengan metode yang ada namun diperlukan modifikasi. Metode estimasi evaporasi waduk yang terbaik adalah Modified Schendel, namun belum bisa menunjukkan variasi spasial yang sesuai observasi. Penggunaan regresi Linier Berganda dan menambahkan parameter radiasi matahari pada Modified Schendel, didapatkan suatu persamaan yang baik secara statistik dan dapat menunjukkan variasi spasial evaporasi di Waduk Saguling yang sesuai observasi.
\end{abstract}

Kata Kunci : Evaporasi, Himawari, MODIS, Satelit, Waduk.

\begin{abstract}
An evaporation estimation of a reservoir area which uses satellite data input-based empirical method were conducted to resolve the lack of meteorological data from ground meteorological stations. Satellite data in the form of land surface temperature from Himawari satellite and atmospheric profile from MODIS satellites were used to obtain informations on temperature, relative humidity, and solar radiation parameters. These were done to quantitatively estimate evaporation on the reservoir. Among the empirical methods used were; The Blaney-Criddle, Kharuffa, Hargreaves, Schendel, and Modified Schendel. Evaporation estimation results were then compared to reference evaporation, which is calculated by using a combination method (Penman) with the meteorological parameters input obtained from observations. Observations were carried out by using Automatic Weather Station at two observation points in The Saguling Reservoir. The result shows that the satellite data-based estimation can be done with the afromentioned methods but with additional modifications. It was found that The Modified Schendel Method is the best estimation method for reservoir evaporation. However this method has not been able to account for spatial variation that are present in the observations. It was also found that the use of multiple linear regression and the addition of solar radiation parameter into the Modified Schendel model, would result in a statistically good equation. In addition, the inclusion of the two new parameters into the model can account for spatial variation of evaporation in The Saguling Reservoir, in accordance with the observation.
\end{abstract}

Keywords: Evaporation, Himawari, MODIS, Satellite, Reservoir. 


\section{PENDAHULUAN}

Evaporasi memiliki peranan penting dalam proses iklim, atmosfer dan pertanian lokal (Ramamurthy \& Bou-Zeid, 2014). Proses evaporasi menentukan kadar uap air di atmosfer yang merupakan salah satu faktor penting untuk keberlangsungan proses pembentukan awan dan presipitasi. Evaporasi badan air adalah komponen penting dari siklus energi dan hidrologi untuk waduk (Granger \& Hedstrom, 2010). Evaporasi air terbuka seperti penguapan waduk dapat menunjukkan evaporasi potensial regional (Vercauteren et al., 2009). Informasi nilai evaporasi potensial diperlukan dalam menganalisis kesetimbangan air, perencanaan irigasi, manajemen sumber daya air, perencanaan sumber daya lahan, dan banjir (Xu \& Singh, 1998). Informasi evaporasi waduk juga penting untuk mengetahui signifikansi kehilangan air akibat evaporasi. Hilangnya air akibat evaporasi dapat mencapai $90-95 \%$ dari total kehilangan air danau atau waduk (Khobragade et al., 2016).

Pada umumnya, jumlah stasiun pengukuran di wilayah waduk yang luas masih sangat terbatas, sehingga informasi evaporasi secara spasial dan temporal masih minim. Oleh sebab itu, studi mengenai estimasi evaporasi diperlukan. Berbagai metode estimasi evaporasi telah dikembangkan untuk menghasilkan nilai evaporasi yang akurat. Metode fisik yang kompleks membutuhkan lebih banyak variabel dan parameter sehingga metode tersebut sesuai untuk kondisi iklim yang bervariasi. Namun, metode tersebut membutuhkan data meteorologi yang sangat detail dan sering tidak tersedia dari stasiun meteorologi (Jabloun \& Sahli, 2008). Estimasi evaporasi menggunakan data satelit banyak dikembangkan namun masalah utamanya tetap pada kebutuhan input tambahan berupa data parameter meteorologi yang tidak tersedia dari stasiun. Maeda et al. (2011) telah memberikan contoh penggunaan satelit MODIS tanpa adanya inputan dari data stasiun. Hasil penelitiannya menunjukkan kombinasi metode estimasi secara empiris dengan data satelit menyediakan alternatif untuk memperoleh informasi evaporasi berkelanjutan secara spasial dan temporal.

Pada penelitian ini dilakukan estimasi evaporasi menggunakan metode empiris dengan input data satelit serta menentukan metode estimasi terbaik untuk daerah waduk. Dalam studi ini, lokasi Waduk Saguling-Jawa Barat dijadikan sebagai studi kasus karena kahadiran waduk ini sangat penting untuk keperluan berbagai bidang, seperti energi, pangan, ketersediaan air, dan juga pariwisata. Nilai acuan evaporasi didapatkan dengan melakukan pengamatan menggunakan Automatic Weather Station (AWS) di dua titik di wilayah waduk (dapat dilihat pada Gambar 1).

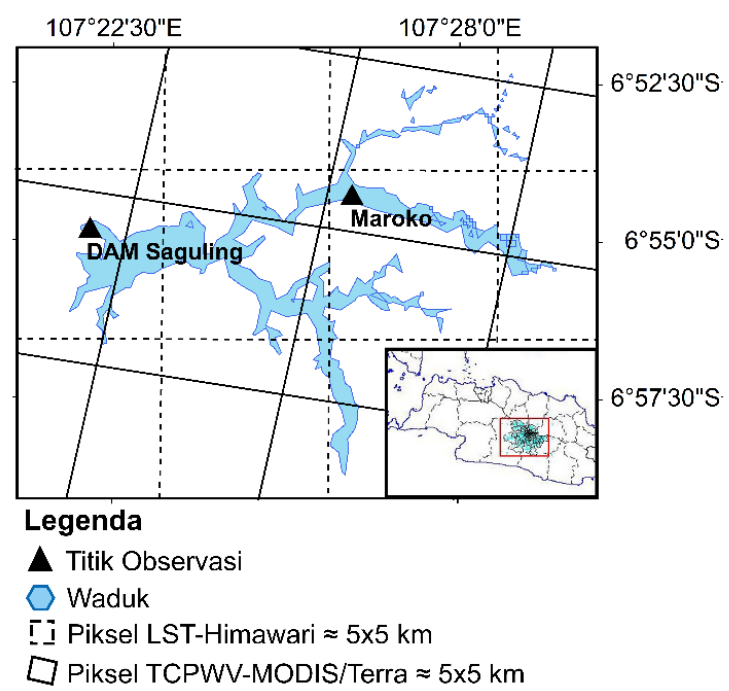

Gambar 1. Lokasi penelitian di wilayah Waduk Saguling-Jawa Barat, titik pengambilan data meteorologi oleh Automatic Weather Station (AWS), dan piksel Himawari dan MODIS.

\section{METODE}

\subsection{Estimasi Evaporasi}

Estimasi evaporasi dilakukan menggunakan metode empiris, yaitu metode yang dibangun dari data meteorologi dari stasiun permukaan. Salah satu metode empiris yang sering digunakan adalah metode temperatur seperti yang telah dievaluasi dan digeneralisasi oleh Xu \& Singh (2001). Dalam penelitiannya dievaluasi tujuh metode temperatur. Empat metode yang dapat diaplikasikan untuk estimasi evaporasi dengan input data satelit antara lain Blaney Criddle, Kharuffa, Hargreaves, dan Schendel. Keempat metode tersebut dipilih karena hanya membutuhkan parameter temperatur $(\mathrm{T})$ dan kelembapan relatif $(\mathrm{RH})$. $\mathrm{T}$ dan $\mathrm{RH}$ dari satelit memiliki kemampuan yang cukup baik dalam menjelaskan kedua parameter sesuai observasi dengan $R^{2}$ mulai $0,60-0,66$ untuk $T$ dan $0,44-0,57$ untuk RH seperti pada Gambar 2 .

Tabel 1 menunjukkan persamaan keempat metode yang digunakan. $\mathrm{E}$ adalah evaporasi $(\mathrm{mm} /$ hari), $\mathrm{P}$ adalah rata-rata persentase lama penyinaran matahari, $R_{A}$ adalah radiasi ektraterestrial, $\mathrm{T}$ adalah temperatur rata-rata $\left({ }^{\circ} \mathrm{C}\right)$ dan $\mathrm{RH}$ adalah kelembapan relatif (\%). Radiasi ektraterestrial harian dan rata-rata persentase lama penyinaran matahari diperoleh berdasarkan tabel ketentuan FAO (1986).

$\mathrm{T}$ didapatkan dari Land Surface Temperatur (LST) satelit Himawari yang merupakan produk LST Version 1 Land Service of Copernicus yang diunduh melalui https://land.copernicus.vgt.vito.be/. LST adalah fungsi dari TOA Brightness Temperature kanal 14 dan 15 panjang gelombang $11 \mu \mathrm{m}$ dan $12 \mu \mathrm{m}$ menggunakan algoritma Generalized Split-Window (Freitas et al., 2010). LST dari satelit Himawari beresolusi temporal satu jam. 

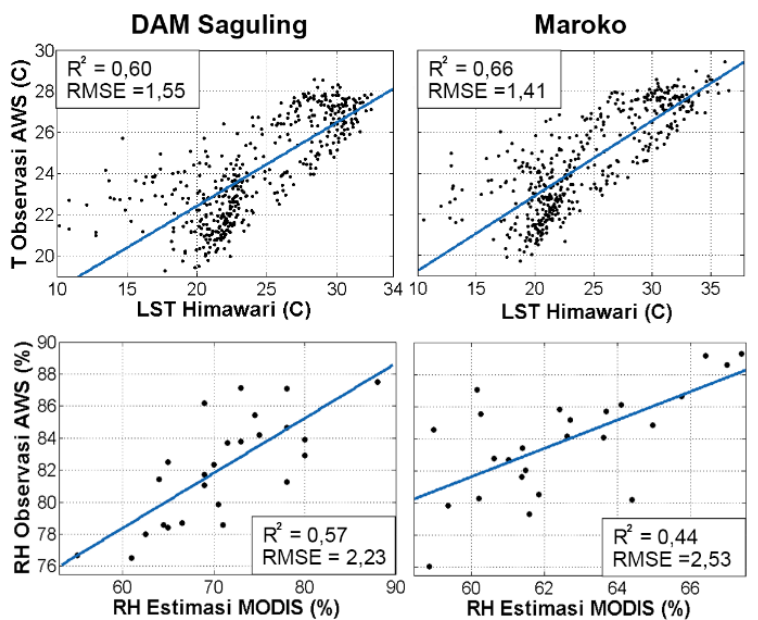

Gambar 2. Scatter plot data satelit dengan data observasi AWS, baris pertama untuk temperatur

(T) dan baris kedua untuk kelembapan relatif $(\mathrm{RH})$.

Tabel 1. Metode Temperatur

\begin{tabular}{clc}
\hline No. & \multicolumn{1}{c}{ Metode } & \multicolumn{1}{c}{ Persamaan } \\
\hline $\mathbf{1}$ & $\begin{array}{l}\text { Blaney- } \\
\text { Criddle }(\mathrm{BC})\end{array}$ & $\mathrm{E}=\mathrm{P}(0,46 \mathrm{~T}+8)$ \\
\hline $\mathbf{2}$ & Kharuffa $(\mathrm{Kf})$ & $\mathrm{E}=0,34 \mathrm{P}(\mathrm{T})^{1,3}$ \\
\hline $\mathbf{3}$ & $\begin{array}{l}\text { Hargreaves } \\
(\text { Hg) }\end{array}$ & $\mathrm{E}=0,0023 \mathrm{R}_{\mathrm{A}}(\mathrm{Tmax}-$ \\
$\mathrm{Tmin}) 1 / 2(\mathrm{~T}+17,8)$ \\
\hline $\mathbf{4}$ & Schendel $(\mathrm{Sd})$ & $\mathrm{E}=16(\mathrm{~T} / \mathrm{RH})$ \\
\hline
\end{tabular}

$\mathrm{RH}$ didapatkan dari produk profil atmosferik (MOD07_L2 dan MYD07_L2) satelit MODIS Aqua/Terra yang diunduh pada https://ladsweb.modaps.eosdis.nasa.gov/. Profil atmosferik menyediakan parameter Total Column Precipitable Water Vapor (TCPWV) yang akan diolah menjadi nilai RH. Nilai TCPWV dalam $\mathrm{cm}$ didapatkan menggunakan Persamaan 1 (Borbas et al., 2011).

Nilai $\mathrm{RH}$ dengan resolusi harian didapatkan melalui Persamaan 2 yang dirumuskan oleh Sofan et al. (2007) untuk estimasi RH di wilayah Jawa Barat pada ketinggian 600-700 m. Hal ini disesuaikan dengan elevasi titik pengamatan yaitu $\pm 642 \mathrm{~m}$.

TCPWV $=$ faktor skala $\times($ nilai piksel-add offset) $\ldots$

$\mathrm{RH}=2,5351 \mathrm{TCPWV}+53,803$

$\mathrm{RH}$ tidak didapatkan dari satelit Himawari yang memiliki resolusi temporal tinggi karena algoritma yang sangat kompleks untuk mendapatkan profil atmosferik seperti pada penelitian yang dilakukan oleh Lee et al. (2017). Satelit MODIS dipilih karena telah menyediakan profil atmosferik yang dapat langsung diolah untuk mendapatkan parameter $\mathrm{RH}$ dengan Persamaan 2.

\subsection{Pengolahan Data Observasi AWS}

Untuk mendapatkan metode estimasi terbaik, hasil estimasi evaporasi akan dibandingkan dengan evaporasi acuan. Nilai evaporasi acuan didapatkan dengan melakukan pengamatan menggunakan AWS selama 35 hari yaitu 4 Mei - 7 Juni 2018 di dua titik wilayah Waduk Saguling yaitu DAM Saguling dan Maroko seperti pada Gambar 1. Kajian difokuskan pada kondisi hari tidak hujan. Selama pengamatan, sampel data dengan kondisi tidak hujan yang digunakan adalah 20 hari untuk Maroko dan 17 hari untuk DAM Saguling. Pengamatan dilakukan di atas permukaan air sesuai pedoman World Meteorological Organization (WMO-No.168) tentang pengukuran untuk estimasi evaporasi waduk. Parameter meteorologi hasil pengukuran AWS yang digunakan antara lain temperatur, kelembapan relatif, tekanan udara, kecepatan angin, radiasi matahari dan curah hujan. Paramater tersebut diambil dengan interval data 10 menit.

Diagram Taylor (Taylor, 2001) digunakan untuk mengetahui seberapa dekat nilai evaporasi hasil estimasi menggunakan input data satelit dengan nilai evaporasi acuan. Kesamaan antara dua pola dihitung dengan tiga indeks statistik yaitu Koefisien Korelasi Pearson, Root Mean Square Difference (RMSD), dan Standar Deviasi (STD).

Metode kombinasi yang dirumuskan oleh Penman $(1948,1956)$ untuk evaporasi permukaan air terbuka digunakan sebagai nilai evaporasi acuan. Metode kombinasi ini menggabungkan metode aerodinamik dan kesetimbangan energi yang diturunkan seperti pada Persamaan 3 dan Persamaan 4, sebagai berikut:

$E=\frac{\lambda E}{\lambda \rho_{w}}$.

$\lambda E=\frac{\Delta\left(R_{n}-Q_{t}\right)+\gamma E_{a}}{\Delta+\gamma}$.

Dengan $\mathrm{E}$ adalah evaporasi (mm/hari), $\lambda E$ adalah panas laten evaporasi $\left(\mathrm{MJ} / \mathrm{m}^{2}\right), \lambda$ adalah panas laten penguapan $(\mathrm{MJ} / \mathrm{kg})$, $\rho \mathrm{w}$ densitas air $\left(\mathrm{kg} / \mathrm{m}^{3}\right), \gamma$ adalah konstanta psikrometrik $\left(\mathrm{kPa} /{ }^{\circ} \mathrm{C}\right)$, $\Delta$ adalah slope of saturation vapor pressure curve $\left(\mathrm{kPa} /{ }^{\circ} \mathrm{C}\right), \quad\left(R_{n}-Q_{t}\right)$ adalah radiasi bersih dikurangi perubahan simpanan energi $\left(\mathrm{MJ} / \mathrm{m}^{2}\right)$, dan Ea adalah ekspresi bulk aerodinamik yang mengandung fungsi empiris angin $\left(\mathrm{MJ} / \mathrm{m}^{2}\right)$.

Perubahan energi simpanan harian dihitung menggunakan persamaan yang dirumuskan Jensen (2010) seperti terlihat pada Persamaan 5 dan Persamaan 6.

$Q t=0,5 R_{n s}-0,8 R_{n l}$ untuk hari $<180$

$\mathrm{Qt}=0,5 \mathrm{R}_{\mathrm{ns}}-1,3 \mathrm{R}_{\mathrm{nl}}$ untuk hari $>180$

$R_{n s}$ adalah radiasi bersih gelombang pendek dan $R_{n l}$ adalah radiasi bersih gelombang panjang. Perhitungan untuk mendapatkan nilai $R_{n s}$ dan $R_{n l}$ dilakukan melalui beberapa langkah perhitungan seperti pada Zotarelli et al. (2015). 
Perubahan energi simpanan (Qt) digunakan sebagai pengganti fluks panas tanah (G) karena Qt dibentuk oleh konduksi dan penetrasi sedangkan $G$ dibentuk hanya oleh konduksi termal. Terdapat perbedaan utama dalam perhitungan radiasi bersih untuk daratan dan permukaan air. Untuk daratan, radiasi bersih dikonversi menjadi panas sensibel dan panas laten pada tanah atau permukaan tumbuhan. Sedangkan untuk permukaan air, radiasi bersih tidak sepenuhnya diserap pada permukaan air, sebagian dari radiasi bersih dapat menembus (terpenetrasi) ke kedalaman air yang jernih. Radiasi matahari yang diserap di bawah permukaan air disimpan sebagai energi dan tidak langsung digunakan untuk evaporasi (Jensen, 2010).

Data observasi juga digunakan untuk memodifikasi persamaan Schendel. Suatu persamaan evaporasi membutuhkan adanya kalibrasi terhadap suatu kondisi saat akan diaplikasikan, karena bias yang besar dapat dihasilkan dari penggunaan persamaan empiris yang sudah dikalibrasi untuk wilayah yang berbeda (Xu \& Singh, 1998). Suatu persamaan dapat dikalibrasi menggunakan metode automatic optimization seperti yang telah dilakukan oleh Suwarman et al. (2018). Kalibrasi menghasilkan Persamaan 7 yaitu Modified Schendel (MSd) dengan $\mathrm{C}$ adalah konstanta yang bernilai 8 .

$M S d=C \frac{T}{R H}$

\section{HASIL DAN PEMBAHASAN}

Perbandingan hasil estimasi menggunakan kelima metode dengan evaporasi acuan dapat dilihat pada Gambar 3. Blaney-Criddle (BC), Hargreaves $(\mathrm{Hg})$, Kharuffa $(\mathrm{Kf})$, dan Schendel (Sd) dengan input data satelit memiliki hasil yang jauh melebihi evaporasi acuan (overestimate) di kedua titik pengamatan yaitu DAM Saguling dan Maroko. Evaporasi acuan ada pada kisaran nilai 3 $\mathrm{mm} /$ hari sedangkan hasil estimasi keempat metode ada pada kisaran 4-7 mm/hari. Secara umum, metode Schendel dan Modified Schendel dapat mengikuti pola evaporasi acuan dengan baik. Modified Schendel (MSd) mampu mengikuti pola dan berada pada rentang nilai yang dekat dengan evaporasi acuan walaupun masih lebih tinggi (overestimate) di Maroko dan lebih rendah (underestimate) di DAM Saguling. Sedangkan metode Schendel, walaupun lebih mengikuti pola acuan, namun masih terdapat perbedaan nilai yang jauh. Nilai korelasi Sd adalah 0.85 untuk DAM Saguling dan 0.57 untuk Maroko, sedangkan untuk Msd adalah 0.84 untuk DAM Saguling dan 0.57 untuk Maroko. Nilai korelasi Sd ataupun Msd merupakan nilai tertinggi di DAM Saguling, namun untuk Maroko, nilai korelasi tersebut hampir berimbang dengan $\mathrm{Kf}$ dan $\mathrm{BC}$ (0.57). Nilai-nilai statistik mengenai hasil metode-metode tersebut dijelaskan lebih lanjut pada diagram Taylor.
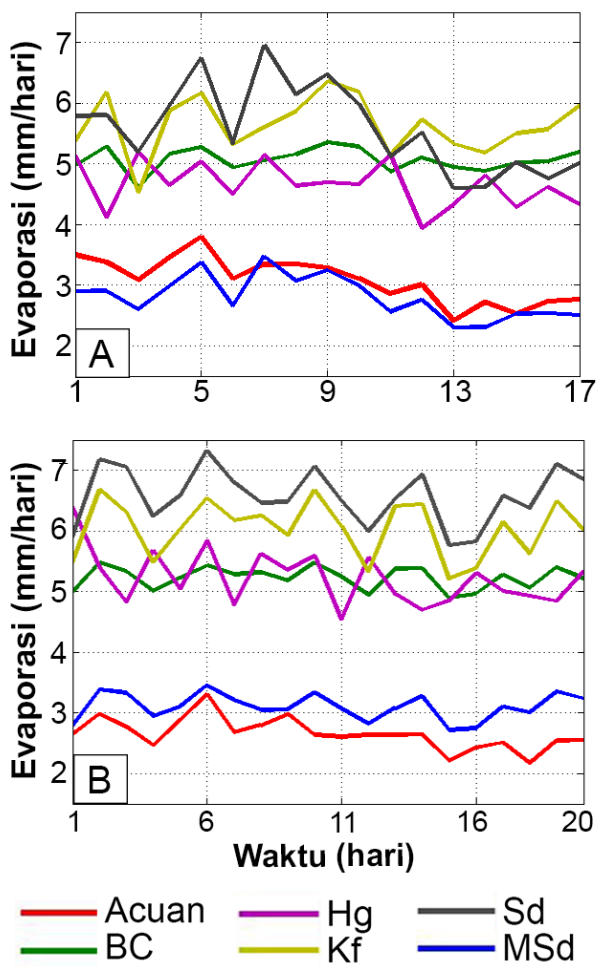

Gambar 3. Perbandingan hasil estimasi evaporasi menggunakan data satelit dengan evaporasi acuan di (a) DAM Saguling dan (b) Maroko.

Gambar 4 menjelaskan hubungan evaporasi dengan parameter meteorologi $T$ (Gambar 4.a), RH (Gambar 4.b) dan Rs (Gambar 4.c) dari data AWS. Gambar tersebut menjelaskan parameter yang paling berpengaruh dari korelasi yang terbesar berurutan adalah $\mathrm{Rs}, \mathrm{RH}$, dan $\mathrm{T}$. $\mathrm{RH}$ berkorelasi negatif terhadap evaporasi yang berarti peningkatan $\mathrm{RH}$ akan diikuti penurunan nilai evaporasi dan sebaliknya. Sedangkan pola hubungan antara $\mathrm{T}$ dan Rs menunjukkan korelasi positif yang berarti jika $T$ dan Rs mengalami peningkatan maka akan terjadi peningkatan nilai evaporasi. Besarnya nilai korelasi $\mathrm{RH}$ terhadap evaporasi ini dapat menjelaskan mengapa metode Schendel dapat mengestimasi nilai evaporasi dengan baik. Hal ini disebabkan metode Schendel menggunakan $\mathrm{RH}$ sebagai salah satu parameter perhitungan, sehingga dapat meningkatkan kemampuan mengestimasi evaporasi. Pola hubungan parameter meteorologi terhadap evaporasi memiliki kesamaan di kedua titik pengamatan yaitu DAM Saguling dan Maroko.

Diagram Taylor menunjukan bahwa metode yang terbaik secara statistik adalah MSd dan BC (Gambar 5). Kedua metode tersebut masih terdapat di dalam lingkaran acuan. Msd memiliki hasil yang konsisten untuk kedua titik dengan korelasi dan RMSD yang baik dan standar deviasi mendekati acuan. 

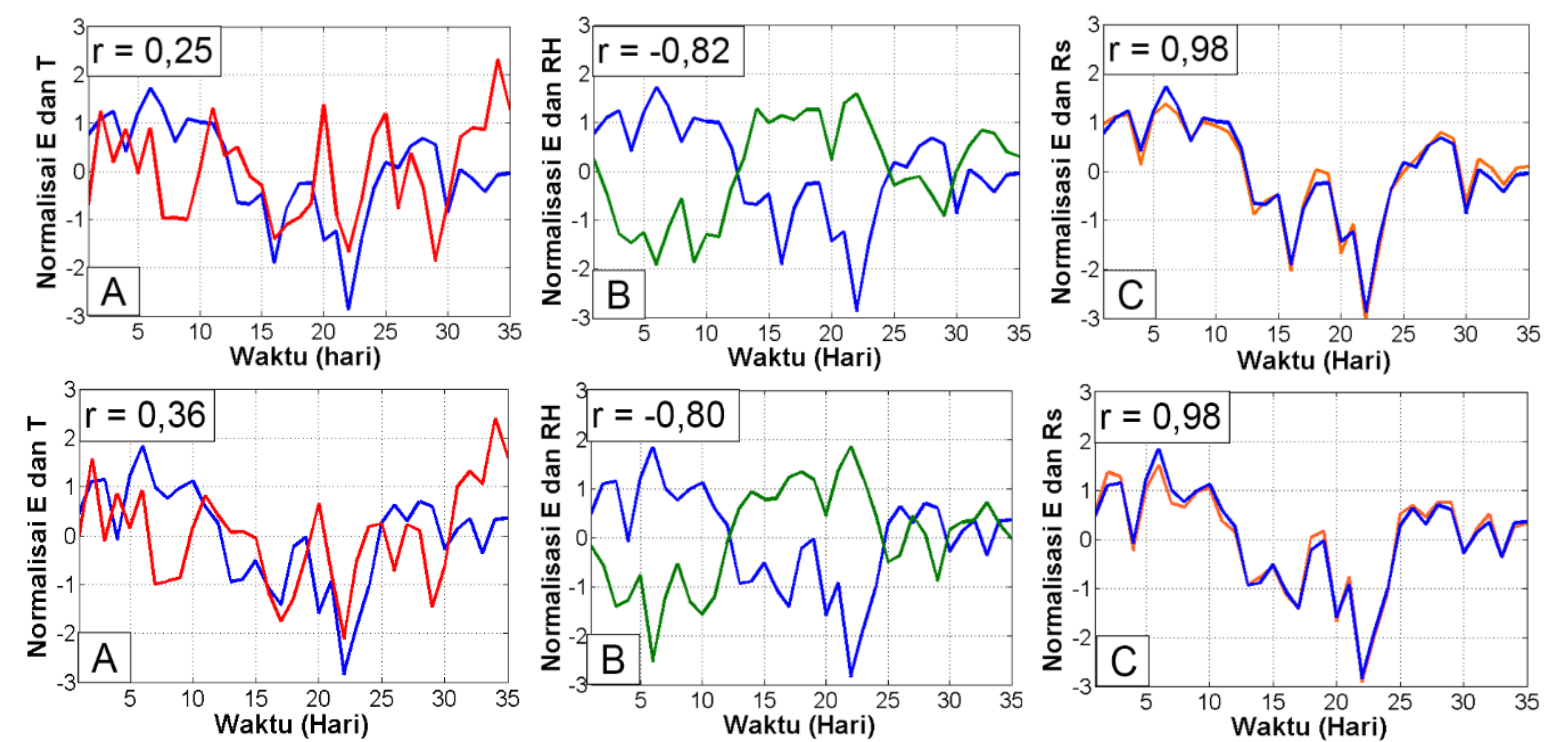

Gambar 4. Pola hubungan evaporasi (garis biru) dengan parameter meteorologi (a) temperatur (garis merah), (b) kelembapan relatif (garis hijau), dan (c) radiasi matahari (garis jingga) berdasarkan data AWS di DAM Saguling (baris atas) dan Maroko (baris bawah).
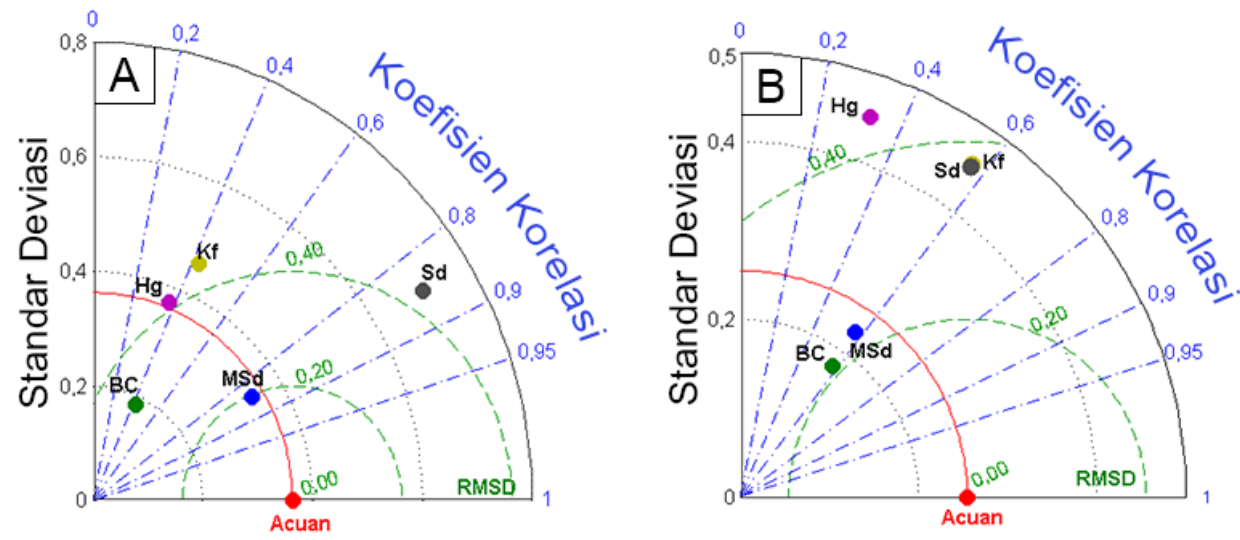

Gambar 5. Diagram Taylor untuk lima metode di (a) DAM Saguling dan (b) Maroko.
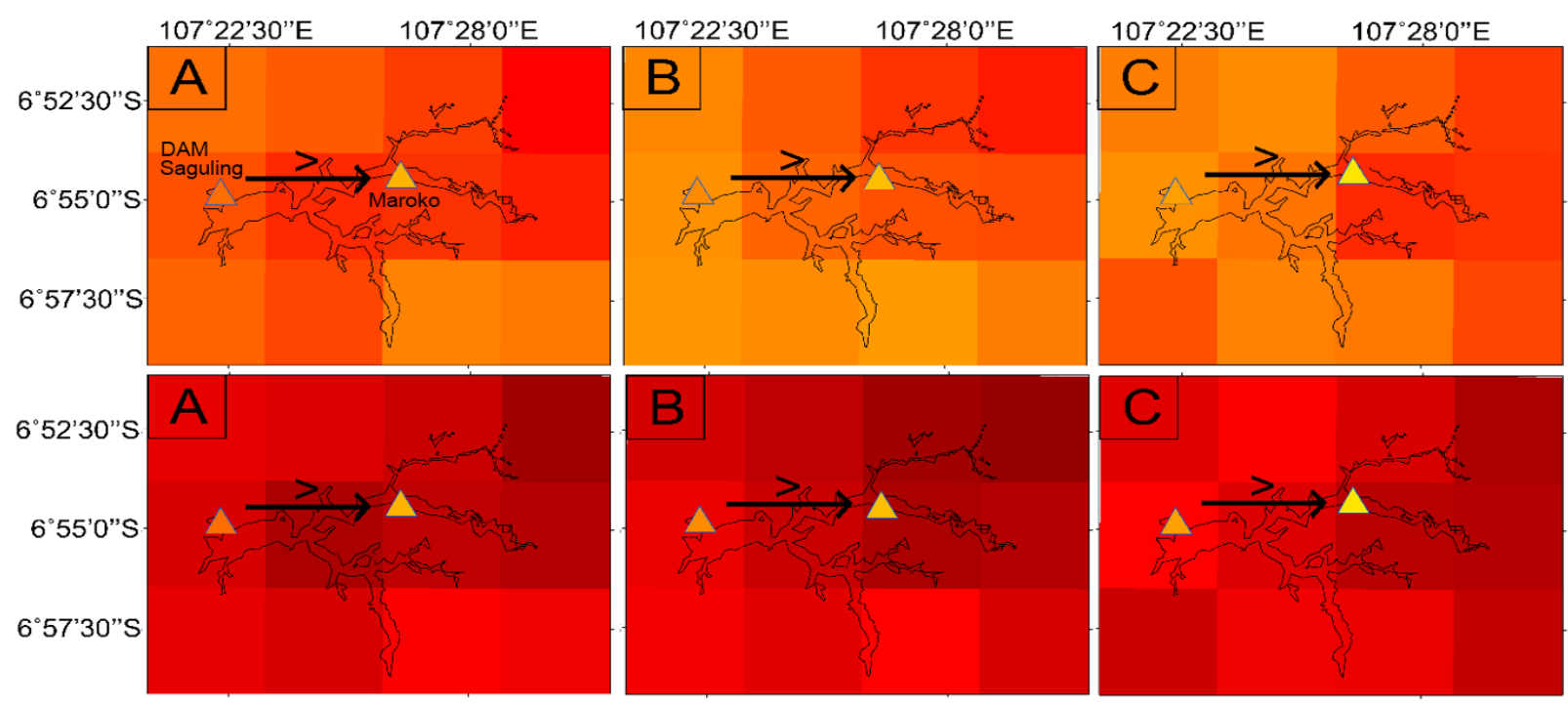

2,49
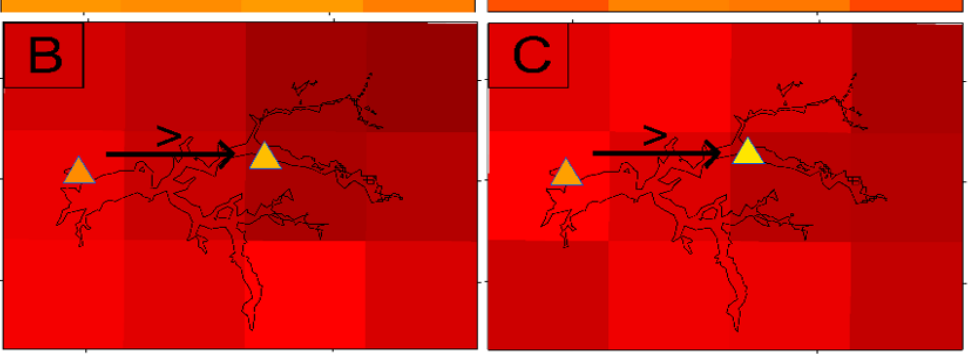

$E(\mathrm{~mm} / \mathrm{hari})$

5,56

Gambar 6. Peta distribusi spasial estimasi evaporasi satelit di Waduk Saguling menggunakan metode Modified Schendel (atas) dan Blaney-Criddle (bawah) pada tanggal (a) 6 Mei, (b) 1 Juni, dan (c) 6 Juni 2018. Segitiga menunjukkan nilai evaporasi acuan sedangkan arah panah dengan simbol $>$ menunjukkan semakin ke timur nilai acuan semakin kecil. 
Gambar 6 adalah peta distribusi spasial estimasi evaporasi berdasarkan data satelit dan acuan. Peta ini digunakan untuk mengetahui kemampuan kedua metode ini dalam menjelaskan variasi spasial evaporasi di Waduk Saguling. Pemilihan tanggal untuk plot spasial didasarkan pada data satelit terlengkap saat hari pengamatan agar dapat memberikan gambaran variasi evaporasi di seluruh Waduk Saguling. Dari peta tersebut dapat dilihat kedua metode belum mampu menunjukkan variasi evaporasi di Waduk Saguling. Sesuai hasil pengamatan, evaporasi di DAM Saguling lebih besar dibandingkan di Maroko atau dengan kata lain semakin ke timur semakin mengecil, namun kedua metode menunjukkan hasil yang sebaliknya.

Untuk mendapatkan metode estimasi yang lebih baik lagi, modifikasi persamaan Schendel dilakukan dengan menggunakan Regresi Linier Berganda (RLB). Modifikasi ini dilakukan dengan menambahkan parameter Rs. Hal ini dipertimbangkan karena adanya korelasi yang kuat antara Rs dan evaporasi seperti yang dijelaskan sebelumnya (Lihat Gambar 4.c). Rs diestimasi menggunakan model radiasi yang dirumuskan oleh Lopez dan Batlles (2014) dengan Persamaan 8-15.

$$
\begin{aligned}
& H_{g}=0,98 e^{\frac{0,07 z}{83453}} e^{f 1(T C P W V, \beta)} H^{f 2(T C P W V, \beta)} f_{3}(\rho, \beta)(8) \\
& f_{1}=-0,249 T C P W V^{0,31225}+2,81375 \beta^{2}-
\end{aligned}
$$$$
2,5948 \beta \text {. }
$$

$f_{2}=1,00324+0,03483 T C P W V^{0,28073}-$

$0,97226 \beta^{2}-0,64794 \beta$.

$f_{3}=0,98613+0,0705 \rho-0,152258 \beta+$

$0,77513 \rho \beta$.

$H=\frac{D l}{\pi} I_{S C} E_{0}\left(1,019-5,5 \times 10^{-4} \emptyset\right)[0,956 \cos \delta$

$\left.\cos \emptyset\left(\sin \omega_{s r}-\omega_{s r} \cos \omega_{s r}\right)-0,0485 \omega_{s r}\right]$.

$E_{0}=1,00011+0,034221 \cos \Gamma+0,00128 \sin \Gamma+$ $0,000719 \cos 2 \Gamma+0,000077 \sin 2 \Gamma$.

$$
\begin{aligned}
& \left\ulcorner=2 \pi\left(\frac{J-1}{365}\right)\right. \text {. } \\
& \beta=0,015+0,0005 \mathrm{~J}-1,38 \times 10^{-6} \mathrm{~J}
\end{aligned}
$$

Dimana $H_{g}$ adalah radiasi matahari dalam $\mathrm{MJ} / \mathrm{m}^{2}$, $\mathrm{H}$ adalah radiasi global harian untuk atmosfer kering dalam $\mathrm{MJ} / \mathrm{m}^{2}, \beta$ adalah koefisien tubiditas Angstrom, $D_{l}$ adalah panjang hari sebesar 0,0864 S, $I_{S C}$ adalah konstanta matahari sebesar 1367 $\mathrm{W} / \mathrm{m}^{2}, E_{0}$ adalah faktor koreksi eksentrisiti, $\varnothing$ adalah lintang, $\delta$ adalah deklinasi matahari, $\omega_{s r}$ adalah sudut matahari dengan satuan radian, $\mathrm{z}$ adalah elevasi, $\rho$ adalah albedo permukaan $(0,08$ untuk permukaan air), 「 sudut hari dalam satuan radian dan $\mathrm{J}$ adalah nomor hari dalam satu tahun (antara 1-365 atau 366).

Modified Schendel yang didapatkan dengam metode RLB dapat dilihat Persamaan 16 dan 17.

$M S d_{1}=0,06366 \frac{T \cdot R s}{R H}+2,2661$

$M S d_{2}=-1,4538 \frac{T}{R H}+0,27505 R s-2,8268 \ldots$

Diagram Taylor pada Gambar 7 menunjukan bahwa $M S d_{2}$ mengasilkan estimasi yang lebih baik untuk kedua titik dibandingkan dengan $M S d_{1}$. Walaupun $M S d_{1}$ memiliki korelasi dan RMSD yang lebih baik namun standar deviasi sangat kecil dan mempunyai nilai jauh dari acuan. Kemampuan $\mathrm{MSd}_{2}$ untuk menunjukkan variasi spasial evaporasi di waduk Saguling juga dapat dilihat pada Gambar 8. Estimasi evaporasi dengan $\mathrm{MSd}_{2}$ menunjukkan evaporasi di DAM Saguling lebih besar dibandingkan Maroko, atau semakin ke timur evaporasi semakin mengecil. Hal ini tersebut sesuai dengan kondisi nilai acuan yang dihasilkan oleh observasi AWS. Dapat dikatakan bahwa $\mathrm{MSd}_{2}$ merupakan metode terbaik untuk estimasi evaporasi baik dari sisi statistik maupun kemampuan dalam menjelaskan variasi spasial evaporasi di Waduk Saguling.
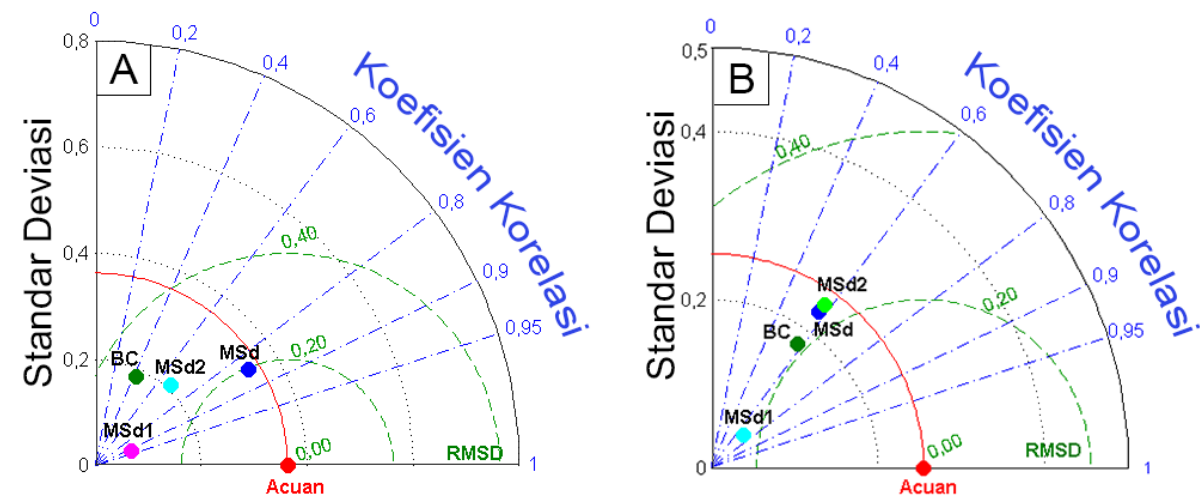

Gambar 7. Sama seperti Gambar 5, tapi untuk metode BC, MSd, MSd ${ }_{1}, M_{S} d_{2}$ di (a) DAM Saguling dan (b) Maroko. 


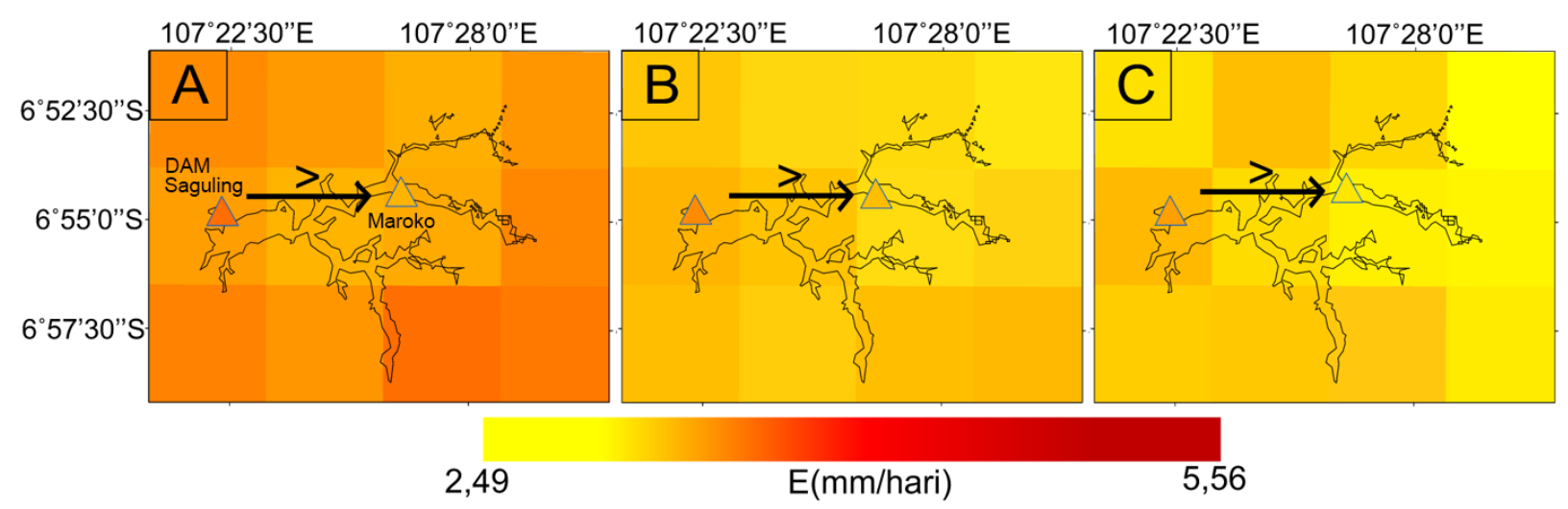

Gambar 8. Sama seperti Gambar 6 tapi untuk metode MSd2.

\section{KESIMPULAN}

Dalam penelitian ini, beberapa metode empirik telah dicoba untuk mendapatkan estimasi evaporasi yang terbaik dengan data satelit di daerah Waduk Saguling. Berdasarkan penjelasan pada bab-bab sebelumnya, beberapa hal dapat disimpulkan, antara lain; estimasi evaporasi waduk dengan kombinasi input data satelit Himawari dan MODIS dapat dilakukan dengan metode persamaan yang sudah ada namun diperlukan modifikasi.

Metode-metode estimasi evaporasi yang telah diuji adalah metode yang berbasis temperatur dan kelembapan relatif, antara lain Blaney Criddle, Kharuffa, Hagreaves, Schendel dan Modified Schendel. Metode-metode tersebut diuji kemampuannya dalam mengestimasi evaporasi di Waduk Saguling. Metode terbaik disimpulkan dari tiga parameter statistik utama, yaitu korelasi, standar deviasi, dan RMSD, yang tertuang dalam diagram Taylor. Selain itu, kemampuan metode-metode tersebut diuji juga dalam menjelaskan variasi evaporasi spasial.

Secara statistic, Modified Schendel (Persamaan 7, MSd) merupakan estimasi yang paling baik. Namun persamaan tersebut belum dapat menunjukan variasi spasial dengan baik. Oleh karena itu, dalam penelitian ini diusulkan dua modifikasi persamaan Schendel dengan menggunakan regresi linier berganda dan penambahan input radiasi matahari (Rs, lihat Persamaan 16 dan 17). Dari kedua modifikasi tersebut didapatkan bahwa Modified Schendel 2 (Persamaan 17, $M S d_{2}$ ) memberikan estimasi evaporasi yang terbaik secara statistik dan kemampuan dalam menunjukan variasi spasial evaporasi yang sesuai dengan nilai evaporasi acuan.

\section{Ucapan Terima Kasih :}

Penelitian ini sebagian didanai oleh Program Penelitian, Pengabdian kepada Masyarakat dan Inovasi ITB (P3MI-ITB). Penulis juga mengucapkan terima kasih pada PT. Indonesia Power Unit Pembangkitan (UP) Saguling yang telah membantu kegiatan penelitian selama observasi.

\section{DAFTAR PUSTAKA}

Borbas, E.E., Seemann, S.W., Kern, A., Moy L., Li, J., Gumley, L., Menzel, W.P. (2011). Modis Atmospheric Profile Retrieval Algorithm Theoretical Basis Document Collection 6. University of Wisconsin-Madison.

Freitas, S.C., Trigo, I.F., Bioucas-Dias, J.M., Göttsche, F.M. (2010). Quantifying the Uncertainty of Land Surface Temperature Retrievals from SEVIRI/Meteosat, IEEE Transactions on Geoscience and Remote Sensing, 48(1), 523-534. doi: 10.1109/TGRS.2009.2027697.

Granger, R.J., Hedstrom, N. (2010). Controls on Open Water Evaporation. Hidrology and Earth System Sciences, 7, 2709-2726. doi: 10.5194/hessd-7-2709-2010

Jabloun, M., Sahli, A. (2008). Evaluation of FAO56 Methodology for Estimating Reference Evapotranspiration Using Limited Climatic Data: Application to Tunisia. Agricultural Water Management, 95(6), 707-715. doi: 10.1016/j.agwat.2008.01.009

Jensen, M.E. (2010). Estimating Evaporation from Water Surfaces. CSU/ARS Evapotranspiration Workshop, Fort Collins, CO, 15-Mar-2010.

Khobragade, S.D., Semwal P., Kumar, A.R.S., Nainwal, H.C. (2016). Significance of Evaporation in Water Availability of Shallow Sub-tropical Lake in India. Octa Journal of Environmental Research, 4(3), 252-263.

Lee, S.J., Ahn, M.H., Chung, S.R. (2017). Atmospheric Profile Retrieval Algorithm for Next Generation Geostationary Satellite of Korea and Its Application to the Advanced Himawari Imager. Remote Sensing, 9(12), 1294. doi:10.3390/rs9121294

Lopez, G., Batlles, F.J. (2014). Estimating Solar Radiation from MODIS Data. Energy Procedia, 49, $2362-2369$.

Maeda, E.E., Wiberg, D.A., Pellikka, P.K.E. (2011). Estimation Reference Evapotranspiration Using Remote Sensing and Empirical Models in Region with Limited Ground Data Availability in Kenya. Applied Geography, 31(1). doi: 10/1016/j.apgeog.2010.05.011 
Penman, H.L. (1948). Natural Evaporation from Open Water, Bare Soil and Grass. Proceedings of Royal Society of London, A193, 120-145. doi: 10.1098/rspa.1948.0037

Penman, H.L. (1956). Evaporation: An Introductory Survey. Netherlands Journal of Agicultural Science, 4, 9-29.

Ramamurthy, P., Bou-Zeid, E. (2014). Contribution of Impervious Surfaces to Urban Evaporation. Water Resources Reseach, 50(4). doi: 10.1002/2013WR013909.

Sofan, P., Sugiharto, T., Hasnaeni. (2007). Relative Humidity Estimation Based on MODIS Precipitable Water for Supporting Spatial Information over Java Island. International Journal of Remote Sensing and Earth Sciences, 4, 33-45. doi: 10.30536/j.ijreses.2007.v4.a1215

Suwarman, R., Junnaedhi I.D.G.A., Novitasari. (2018). A Study on Characteristics and Comparison of Evaporation Estimation Methods in Bandung. Makalah (belum diterbitkan).

Taylor, K.E. (2001). Summarizing Multiple Aspects of Model Performance in a Single Diagram. Journal of Geophysical Research:
Atmospheres, 106(D7), 7183-7192. doi: 10.1029/2000JD900719

Vercauteren, N., Bou-Zeid, E., Huwald, H., Parlange, M.B., Brutsaert, W. (2009). Estimation of Wet Surface Evaporation from Sensible Heat Flux Measurements. Water Resources Research, 45(6). doi: 10.1029/2008WR007544

Xu, C.Y. Singh, V.P. (1998). Dependence of Evaporation on Meteorological Variables at Different Time-scales and Intercomparison of Estimation Methods. Hydrological Processes, 12(3), 429-442. doi: $10.1002 /(\mathrm{SICl}) 1099$ 1085(19980315)12:3<429::AIDHYP581>3.0.CO;2-A

Xu, C.Y. Singh, V.P. (2001). Evaluation and Generalization of Temperature-based Methods for Calculating Evaporation. Hydrological Processes, 15(2), 305- 319. doi: 10.1002/hyp.119

Zotarelli, L., Dukes, M.D., Romero, C.C., Migliaccio, K.W., Morgan, K.T. (2015). Step by Step Calculation of the PenmanMonteith Evapotranspiration (FAO-56 Method). Agricultural and Biological Engineering Departement, UF/IFAS Extention. 